\title{
Nutrition evaluation of sesame seed meal, Sesamum indicum (L.) as alternative protein source in diets of juvenile mono-sex Nile tilapia (Oreochromis niloticus).
}

\author{
Deyab, D. M. S. El-Saidy ${ }^{1}$; Samy, H. Mahmoud ${ }^{2}$; Mostafa, A. El- \\ Garhy ${ }^{2}$ and Hayam D. Tonsy ${ }^{2}$ \\ 1- Department of Poultry Production, Faculty of Agriculture, University of \\ Minufiya, Shebin El-Kom, Egypt. \\ 2- Animal Production Research Institute, Utilization By-Products Department, \\ Agriculture Research Center, Dokki, Giza, Egypt.
}

\begin{abstract}
$\mathrm{T}$ he main objective of this study was to evaluate the effect of partial and total replacement of fish meal protein by sesame seed meal (SSM) protein in commercial diets on growth performance, feed utilization and body composition of juvenile mono sex Nile tilapia, Oreochromis niloticus (L.). Fish of an average initial weight of $0.60 \pm 0.01 \mathrm{~g}$ were stocked in 15 glass aquaria ( 80 1 each) at a rate of 15 fish per aquarium. Fish meal protein (18\% of the diet) was used as the sole source of animal protein in the control diet. Percent replacements of fish meal by sesame seed meal on the basis of crude protein were as follows: $0 \%($ control $\operatorname{diet} \mathrm{A}), 25 \%(\operatorname{diet} \mathrm{B}), 50 \%(\operatorname{diet} \mathrm{C}), 75 \%(\operatorname{diet}$ D) and $100 \%$ (diet E). All tested diets were almost isonitrogenous and fed at a rate of $4 \%$ of fish body weight, and then gradually reduced to $3 \%$ of the total fish biomass daily, for a period of 16 weeks. The results of this study revealed that, fish fedon diet A (100\% FM) had the highest average body weight, specific growth rate (SGR), weight gain \%, feed conversion ratio (FCR), and protein efficiency ratio (PER), but the lowest was obtained with fish fed diet E (100\% SSM). The same parameters of fish fed on diets B (25\% SSM) and diet C (50\% $\mathrm{SSM})$ were not significantly different $(\mathrm{P}>0.01)$ from those of fish fed on the control diet A. Proximate composition of the whole body moisture and ash contents were not significantly affected $(\mathrm{P}>0.05)$ by the dietary treatments. Whole body protein contents for fish fed on diets B, C and D were superior to the control diet. Incorporation of sesame seed meal in the fish diets increased significantly whole body fat content. Incorporation of sesame seed meal in the diets significantly increased apparent digestibility coefficients of crude protein, crude fat and energy. Therefore, these results suggest that up to $50 \%$ of fish meal protein can be replaced by sesame seed protein in mono sex Nile tilapia diets without any adverse effect on growth performance and feed utilization, body composition and digestibility.
\end{abstract}

Key words: mono sex male Nile tilapia, sesame seed meal, growth, body composition, digestibility.

INTRODUCTION 
The main protein source in fish feeds is most often fish meal. However, the rising cost and uncertain availability of fish meal has necessitated studies at either lowering the fish meal content or substituting fish meal with the more economical plant based proteins such as legumes (De Silva et al., 1988), lupine seed meal (De la Higuera et al., 1988), soybean meal (El-Saidy and Gaber, 1997; Eric et al., 2000; Carter and Hauler, 2000), cottonseed meal (El-Sayed, 1990; ElSaidy, 1999; El-Saidy and Gaber (2004), cluster bean meal (El-Saidy et al., 2005),faba bean meal (Deyab et al., 2006) and cow pea seed meal (Deyab and Aml, 2008) which were reported to be suitable as partial replacements for fish meal.

Sesame (Sesamum indicum L.) seed is a drought-tolerant crop adapted to many soil types (Ram et al., 1990). Full-fat sesame seed and the meal after oil extraction are not only excellent sources of edible nutrients (45 to 50\% lipid, 15 to $20 \%$ protein, and 10 to $15 \%$ carbohydrate (Lee et al., 2005.) and $47.1 \%$ (Mamputu and Buhr, 1995) to 52.9\% crude protein, (Kaneko et al. 2002) respectively. The amino acid composition of the protein is similar to that of soybean meal with the exception of lower lysine (Mamputu and Buhr, 1991) and higher methionine in sesame (Dipasa, 2003). The fiber content of the seed ranges from 2.7 to $6.7 \%$ (Beckstrom-Sternberg and Duke, 1994).

Conversely, some of the factors which limit incorporation of plant oilseeds and their by-products at high levels within aquafeeds for warm water omnivorous/herbivorous fish species (Lim and Dominy, 1991) are low protein contents, amino-acid imbalance and presence of anti-nutritional factors (Wee, 1991). However, the seed contains up to $50 \mu \mathrm{g} / \mathrm{g}$ phytic acid (PA) anti-nutritional factor which reduces the biological availability of zinc, calcium, magnesium and iron (Nahm, 2007) that inhibiting the absorption of these important minerals (Gobi, 1981). Diarra and Usman (2008) reported that soaking is one of the most effective methods of lowering the phytic acid (PA) content of the seed.

Hossain and Jauncey (1989) found that sesame oilseed meal can be included up to $25 \%$ in common carp, Cyprinus carpio L. However, Tacon (1993) suggested that maximum level of its inclusion is $35 \%$ in both omnivorous and herbivorous fish species. Whereas, Mukhopadhyay and Ray (1999) suggested that fermented sesame seed meal protein can replace up to $50 \%$ of FM protein in the diets for rohu fingerling. Although there are some reports on the inclusion of sesame seed meal (SSM) as a source of crude protein in fish feeds, there is little or no documented information on its use as a source of protein in juvenile mono sex males Nile tilapia feeds. Therefore, this study has carried out to determine the feasibility of this sesame seed meal protein as a possible replacement for fish meal protein in practical diets for juvenile mono sex male Nile tilapia, Oreochromis niloticus (L.).

\section{Experimental diets}

\section{MATERIALS AND METHODS}


Five isonitrogenous and isocaloric experimental diets containing approximately $32.4 \%$ crude protein were formulated. Diet A (control); containing $18 \%$ fishmeal protein was formulated to be a high-quality commercial tilapia fish diet. The other four diets (B, C, D and E) contained 25, 50,75 and $100 \%$ sesame seed meal (SSM) protein in replacement of fishmeal protein (Table 1).

In preparing the diets, dry ingredients were first ground to a small particle size (approximately $250 \mu \mathrm{m}$ ) in a Wiley mill. Ingredients were thoroughly mixed and then water was added to obtain a $30 \%$ moisture level. Diets were passed through a mincer machine with $0.5-\mathrm{mm}$ diameter to spaghettilike strands, which were dried under the sun rays for $8 \mathrm{~h}$. After drying the diets were broken up and sieved into the appropriate pellet size.

Table 1: Composition and proximate analysis of the tested diets fed to juvenile mono sex male Nile tilapia (Oreochromis niloticus).

\begin{tabular}{|c|c|c|c|c|c|}
\hline \multicolumn{6}{|c|}{ Diets } \\
\hline & A (Control) & B & C & D & $\mathbf{E}$ \\
\hline & $(100 \% \mathrm{FM})$ & $(25 \%$ SSM $)$ & $(50 \% \mathrm{SSM})$ & $(75 \%$ SSM $)$ & $(100 \% \mathrm{SSM})$ \\
\hline \multicolumn{6}{|l|}{ Ingredient (\%) } \\
\hline Menhaden fish meal $(60 \%$ & 30.00 & 22.50 & 15.00 & 7.50 & 0.00 \\
\hline Sesame seed meal ( $42 \% \mathrm{CP}$ ) & 0.00 & 10.71 & 21.43 & 32.14 & 42.86 \\
\hline Soybean meal $(43.8 \% \mathrm{CP})$ & 27.40 & 27.40 & 27.40 & 27.40 & 27.40 \\
\hline Wheat bran & 10.70 & 10.70 & 10.70 & 10.70 & 10.70 \\
\hline Corn starch & 20.90 & 17.69 & 14.47 & 11.26 & 8.04 \\
\hline Soybean oil & 4.00 & 4.00 & 4.00 & 4.00 & 4.00 \\
\hline Molasses & 2.00 & 2.00 & 2.00 & 2.00 & 2.00 \\
\hline Vit. C. & 0.10 & 0.10 & 0.10 & 0.10 & 0.10 \\
\hline Di Ca-Phosphate & 1.40 & 1.40 & 1.40 & 1.40 & 1.40 \\
\hline Vit. \& Min.Premix ${ }^{1}$ & 2.00 & 2.00 & 2.00 & 2.00 & 2.00 \\
\hline L-Methionine & 0.50 & 0.50 & 0.50 & 0.50 & 0.50 \\
\hline L-Lysine & 0.50 & 0.50 & 0.50 & 0.50 & 0.50 \\
\hline Chromic oxide & 0.50 & 0.50 & 0.50 & 0.50 & 0.50 \\
\hline Total (\%) & 100 & 100 & 100 & 100 & 100 \\
\hline \multicolumn{6}{|c|}{ Proximate composition of tested diets ${ }^{2}$} \\
\hline Dry matter & 92.87 & 93.20 & 93.58 & 92.75 & 93.97 \\
\hline Crude protein & 32.43 & 32.36 & 32.54 & 32.33 & 32.57 \\
\hline Crude fat & 12.80 & 12.61 & 12.53 & 12.69 & 12.64 \\
\hline Ash & 7.10 & 7.50 & 7.80 & 7.80 & 7.90 \\
\hline Crude fiber & 4.10 & 4.30 & 4.31 & 4.52 & 4.61 \\
\hline NFE & 36.44 & 36.43 & 36.28 & 35.41 & 36.25 \\
\hline Met. Energy. ${ }^{3}$ & 3907 & 3887 & 3881 & 3852 & 3891 \\
\hline \multicolumn{6}{|c|}{ 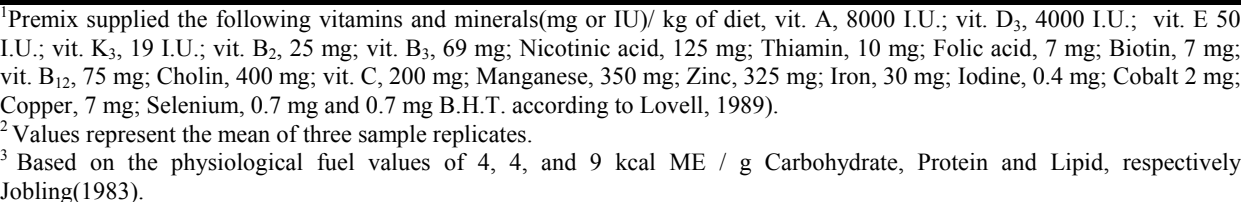 } \\
\hline
\end{tabular}

The proximate compositions of feed ingredients are given in Table (2) and the proximate compositions of each of the diets are given in Table (1). The calculated essential amino acids (EAA) are presented in Table (3). These values 
were calculated based on their ingredients levels presented in Table (1), according to NRC (1993). Percentage protein of the diets was determined by micro-kjeldahl, percentage fat was determined by ether extract method and moisture by drying at $\left(100{ }^{\circ} \mathrm{C}\right)$ until constant weight (AOAC, 1995). Metabolizible energy (ME) was estimated from the diet ingredient according to NRC (1993).

Table 2. Proximate composition of feed ingredients (\%).

\begin{tabular}{|c|c|c|c|c|}
\hline \multirow{2}{*}{$\begin{array}{l}\text { Proximate } \\
\text { Composition\% }\end{array}$} & \multicolumn{3}{|c|}{ Ingredients } & \multirow[b]{2}{*}{ Wheat bran } \\
\hline & $\begin{array}{l}\text { Fish meal } \\
(\mathrm{FM})\end{array}$ & $\begin{array}{l}\text { Sesame seed meal } \\
(\mathrm{SSM})\end{array}$ & $\begin{array}{l}\text { Soybean meal } \\
(\mathrm{SBM})\end{array}$ & \\
\hline Moisture & 8.0 & 8.0 & 6.8 & 3.6 \\
\hline Crude protein & 60.0 & 42.0 & 43.8 & 13.6 \\
\hline Ether extract & 10.5 & 8.0 & 2.2 & 2.9 \\
\hline Crude ash & 16.5 & 11.5 & 6.3 & 12.2 \\
\hline Crude fiber & 1.3 & 6.0 & 7.3 & 7.6 \\
\hline $\mathrm{NFE}^{1}$ & 3.7 & 24.5 & 33.6 & 60.1 \\
\hline $\mathrm{ME}^{2}$ & 3493 & 3380 & 3294 & 3209 \\
\hline
\end{tabular}

\section{Experimental system and animals}

The feeding trial was conducted in 15 glass aquaria each containing 80liter of dechlorinated tap water. About one third of water volume in each aquarium was daily replaced by new aerated fresh water after cleaning and removing of the accumulated excreta. All aquaria were supplied with compressed air for oxygen supply. A photoperiod of 12-h light, 12-h dark (08.00 to $20.00 \mathrm{~h}$ ) was used. Fluorescent ceiling lights has supplied the illumination.

Water temperature and dissolved oxygen were measured every other day, using a YSI Model 58 oxygen meter. Total ammonia and nitrite were measured twice weekly, using a DREL, 2000 spectrophotometer. Total alkalinity and chloride were monitored twice weekly using the titration method; $\mathrm{pH}$ was monitored twice weekly using an electronic $\mathrm{pH}$ meter ( $\mathrm{pH}$ pen; Fisher Scientific, Cincinnati, $\mathrm{OH})$. During the 16-weeks feeding trial, the water-quality parameters averaged $( \pm \mathrm{SD})$ : water temperature, $26.8 \pm 0.9 \mathrm{C}$ : dissolved oxygen, $5.6 \pm 0.7$ $\mathrm{mg} / \mathrm{l}$ : total ammonia, $0.19 \pm 0.12 \mathrm{mg} / \mathrm{l}$ : nitrite, $0.07 \pm 0.03 \mathrm{mg} / \mathrm{l}$ : total alkalinity, $178 \pm 42 \mathrm{mg} / 1$ : chlorides, $570 \pm 152 \mathrm{mg} / \mathrm{l}: \mathrm{pH}, 8.4 \pm 0.3$. All water quality parameters were within the accepted levels for Nille tilapia.

A set of 225 juvenile mono sex Nile tilapia, Oreochromis niloticus (L.) with an average initial weight of $0.6 \pm 0.01 \mathrm{~g}$ were collected from the stock at 
Fish Research Laboratory in Shebin El-Kom, Faculty of Agriculture, Minufiya University and were used for the feeding trial. Fifteen fish were randomly stocked into each aquarium with three replications per treatment. After stocking, to minimize stress of handling, all fish of each aquarium were weighed every 2 weeks and at the end of the feeding trial. All fish were fed, initially, at a rate of 4 $\%$ of the total body weight daily and then gradually decreased to $3 \%$ daily. Fish were fed twice a day (0800 and 1600 h) 6 days per week for 16 weeks.

At the beginning of the study, 30 fish were sampled and frozen at $-18 \circ \mathrm{C}$ for analysis of the whole body composition. At the end of the experiment, a random group of five individual fish were sampled from each aquaria. They were pooled, ground, stored in polyethylene bags and frozen for subsequent body crude protein, lipid, moisture and ash contents determination according to AOAC methods (AOAC, 1995).

Growth performance and feed conversion were measured in terms of final individual fish weight $(\mathrm{g})$, survival rate $(\%)$, specific growth rate (SGR, \% day $^{-1}$ ), feed conversion ratio (FCR), protein efficiency ratio (PER), and food intake ( $\%$ body weight). Growth response parameters were calculated as follows: SGR $\left(\%\right.$ day $\left.^{-1}\right)=\left(\left\{\right.\right.$ In $\left.\left.W_{t}-I n W_{i}\right\} / T\right) \times 100$, where $W_{t}$ is the weight of fish at time $t, W_{i}$ is the weight of fish at time 0 , and $T$ is the rearing period in days: FCR $=$ total dry feed fed $(\mathrm{g}) /$ total wet weight gain $(\mathrm{g}):$ PER $=$ wet weight gain $(\mathrm{g}) /$ amount of protein fed $(\mathrm{g})$ : Feed intake = total dry feed fed (g/fish) (Richardson, et al., 1985).

Apparent nutrient digestibility:

After two-month feeding of experimental diets, feces were collected from each aquarium once daily every morning prior to feeding for a one-month period. The feces were collected on filter paper for drying as described by El-Saidy and Gaber (2002). The chemical analyses were conducted according to AOAC (1995). Chromic oxide was determined according to the procedure described by Furukawa and Tusukahare (1966). Apparent nutrient digestibility was calculated using the formula of Maynard and Loosli (1969).

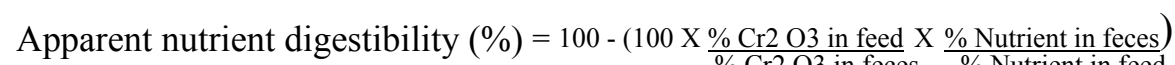

\section{Statistical analysis}

Data were treated by analysis of variance (ANOVA) using the SAS ANOVA procedure (Statistical analysis system, 1988). Duncan's multiple range test (Duncan 1955) was used to compare differences among individual means. Treatment effects were considered significant at $\mathrm{P} \leq 0.05$ levels. All percentage and ratio were transformed to arcsin values prior to analysis (Zar, 1984). 
Table 3: Calculated amino acids contents in different experimental diets and amino acid requirement of tilapia.

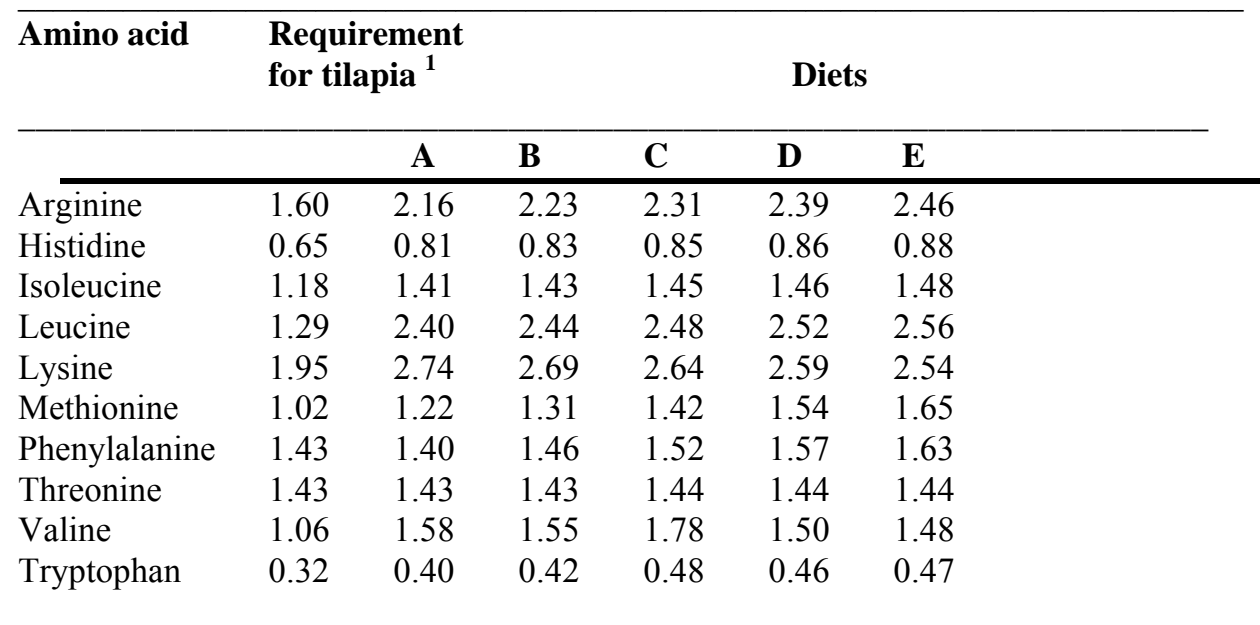

${ }^{1}$ Source: Santiago and Lovell (1988).

\section{RESULTS AND DISCUSSION}

The results of the average final body weight, specific growth rate (SGR), weight gain \%, feed conversion ratio (FCR) and protein efficiency ratio (PER) are presented in Table (4). Fish fed on diet A which contained $100 \%$ fish meal protein showed the best average final body weight, specific growth rate (SGR), weight gain \%, feed conversion ratio (FCR), and protein efficiency ratio (PER). However, the same parameters for diets $\mathrm{B}$ and $\mathrm{C}$ did not differ significantly from those of fish fed on control diet A (100\% FM). Diet E which contained $100 \%$ protein from sesame seed meal resulted in significantly $(\mathrm{P} \leq 0.05)$ lowest average final body weight, specific growth rate (SGR), weight gain \%, feed conversion ratio (FCR), protein efficiency ratio (PER). The unsuitability of complete substitution was further reflected by the observed lack of response of the fish to the test diet at feeding times. The survival rate at the end of the feeding trial was high and recorded $100 \%$ for all groups of fish fed on the experimental diets. In the present study, fish fed on diet A (100\% FM) had faster growth rate and better food utilization than fish fed on diet E (100\% SM). Fish fed on diets B (25\% SSM) and C (50\% SSM) did not differ significantly $(\mathrm{P}>0.01)$ from those of fish fed the control diet A (100\% fish meal protein). The present results exhibited that sesame seed meal protein can replace fish meal protein up to $50 \%$ in practical diets of mono sex Nile tilapia. These findings are in agreement with the results of Jackson et al. (1982), who fed S. mossambicus $(13.9 \mathrm{~g})$ isocaloric, isonitrogenous diets with varying levels of plant protein from cottonseed meal for 9 weeks. The best feed conversion ratio (FCR) and specific growth rate (SGR) were obtained at $50 \%$ cottonseed meal. However, the fish 
grew at a reasonable rate even at a $100 \%$ cottonseed meal inclusion level. Similar results were reported for Tilapia zillii (El-Sayed, 1987), Nile tilapia (E1Sayed, 1990), Carp (Hasan et al., 1997), Nile tilapia (El-Saidy and Gaber, 2001) and Carp (El-Saidy et al., 2005).

Table 4: Growth performance and nutrient utilization of mono sex Nile tilapia fed the experimental diets after 16 weeks (Averages \pm SD).

\begin{tabular}{|c|c|c|c|c|c|}
\hline \multirow[b]{2}{*}{ Parameters } & \multicolumn{5}{|c|}{ Diets } \\
\hline & $\begin{array}{l}\text { A (control) } \\
(100 \% \mathrm{FM})\end{array}$ & $\begin{array}{c}\text { BC } \\
(25 \% \mathrm{SSM})\end{array}$ & $\begin{array}{c}\text { D } \\
(50 \% \text { SSM })\end{array}$ & $\begin{array}{c}\mathbf{E} \\
(75 \% \mathrm{SSM})\end{array}$ & $(100 \% \mathrm{SSM})$ \\
\hline Initial wt. (g/fish) & $0.60 \pm 0.01$ & $0.60 \pm 0.01$ & $0.60 \pm 0.01$ & $0.60 \pm 0.01$ & $0.60 \pm 0.01$ \\
\hline Final wt.(g / fish) & $16.15 \pm 0.15^{\mathrm{a}}$ & $5.98 \pm 0.17^{\mathrm{a}}$ & $15.50 \pm 1.56^{\mathrm{a}}$ & $13.17 \pm 0.25^{\mathrm{b}}$ & $10.73 \pm 0.39^{\mathrm{c}}$ \\
\hline Gain in wt.(g/fish) & $15.55 \pm 0.15^{\mathrm{a}}$ & $15.29 \pm 0.11^{\mathrm{a}}$ & $14.90 \pm 1.55^{\mathrm{a}}$ & $12.54 \pm 0.11^{\mathrm{b}}$ & $10.13 \pm 0.35^{\mathrm{c}}$ \\
\hline Weight gain $(\%)$ & $2595.9 \pm 126.7^{\mathrm{a}}$ & $2466.1 \pm 17.8^{\mathrm{a}}$ & $2442.2 \pm 222.60^{\mathrm{a}}$ & $2096.3 \pm 153.8^{b}$ & $1690.7 \pm 54.5^{\mathrm{c}}$ \\
\hline SGR $\left(\%\right.$ day $\left.^{-1}\right)$ & $3.31 \pm 0.01^{\mathrm{a}}$ & $3.26 \pm 0.01^{\mathrm{a}}$ & $3.25 \pm 0.01^{\mathrm{a}}$ & $3.11 \pm 0.01^{\mathrm{b}}$ & $2.91 \pm 0.02^{\mathrm{c}}$ \\
\hline FCR & $1.72 \pm 0.06^{\mathrm{a}}$ & $1.68 \pm 0.01^{\mathrm{a}}$ & $1.61 \pm 0.01^{\mathrm{a}}$ & $1.66 \pm 0.11^{\mathrm{a}}$ & $1.85 \pm 0.01^{\mathrm{b}}$ \\
\hline PER & $1.80 \pm 0.03^{\mathrm{a}}$ & $1.83 \pm 0.01^{\mathrm{a}}$ & $1.91 \pm 0.01^{\mathrm{a}}$ & $1.88 \pm 0.04^{\mathrm{a}}$ & $1.66 \pm 0.04^{b}$ \\
\hline FER & $0.58 \pm 0.01^{\mathrm{ab}}$ & $0.69 \pm 0.01^{\mathrm{a}}$ & $0.62 \pm 0.01^{\mathrm{a}}$ & $0.61 \pm 0.02^{\mathrm{a}}$ & $0.54 \pm 0.01^{b}$ \\
\hline Feed intake ( $\mathrm{g} /$ fish) & $26.70 \pm 0.15^{\mathrm{a}}$ & $25.70 \pm 0.21^{\mathrm{ab}}$ & $23.90 \pm 1.44^{\mathrm{ab}}$ & $20.76 \pm 1.59^{\mathrm{c}}$ & $18.72 \pm 1.08^{\mathrm{d}}$ \\
\hline Survival rate $(\%)$ & 100 & 100 & 100 & 100 & 100 \\
\hline
\end{tabular}

Values with the same superscript are not significantly different $(\mathrm{P}<0.05)$.

In the present study, however, tilapia which has an accelerated growth rate in much higher water temperatures have shown very significant growth depression with sesame seed meal protein over $50 \%$ of dietary protein (diets D\&E). This growth depression was further reported by the lack of response of the fish to the test diets at feeding times. This is in agreement with the results of Hashim et al., (1994) who reported that winged bean seed meal can not be used as a sole protein source for $O$. niloticus fry. Fish fed winged bean seed meal based diets exhibited low growth performance, feed conversion ratio (FCR) and SGR. El-Saidy \& Gaber (2001) and El-Saidy et al (2005) reported the same results with the Nile tilapia and the common carp, respectively.

Table 5: Chemical analysis of the whole body composition of fish at the start and end of the experiment (Averages $\pm \mathrm{SD})$.

\begin{tabular}{lcccccc}
\hline Components & \multicolumn{1}{c}{ Initial } & \multicolumn{1}{c}{ Diets } & & & \\
& & & A (control) \\
$(0 \% \mathrm{SSM})$ & $(25 \% \mathrm{SSM})$ & $(50 \% \mathrm{SSM})$ & $(75 \% \mathrm{SSM})$ & $(100 \% \mathrm{SSM})$ \\
\hline Moisture & $79.0 \pm 0.7$ & $76.9 \pm 0.4$ & $75.9 \pm 1.1$ & $76.9 \pm 0.3$ & $75.8 \pm 0.8$ & $77.5 \pm 0.7$ \\
Crude protein & $61.3 \pm 2.2$ & $71.1 \pm 0.3^{\mathrm{a}}$ & $72.3 \pm 0.2^{\mathrm{a}}$ & $73.0 \pm 0.5^{\mathrm{a}}$ & $71.2 \pm 0.2^{\mathrm{a}}$ & $65.6 \pm 0.4^{\mathrm{b}}$ \\
Crude lipid & $15.3 \pm 1.4$ & $11.6 \pm 0.4^{\mathrm{b}}$ & $8.6 \pm 0.3^{\mathrm{c}}$ & $12.4 \pm 0.2^{\mathrm{a}}$ & $12.4 \pm 0.03^{\mathrm{a}}$ & $13.8 \pm 0.5^{\mathrm{a}}$ \\
Crude ash & $14.1 \pm 1.3$ & $15.6 \pm 1.2$ & $16.7 \pm 1.3$ & $14.6 \pm 0.3$ & $15.4 \pm 0.3$ & $16.1 \pm 0.5$ \\
\hline
\end{tabular}

Values with the same superscript are not significantly different $(\mathrm{P}<0.05)$.

Table 6: Averages of apparent nutrient digestibility coefficients for mono sex Nile tilapia fingerlings fed on diets with partial and total replacement of fishmeal by sesame seed meal. 


\begin{tabular}{llccc}
\hline & & \multicolumn{3}{c}{ Digestibility coefficients } \\
\cline { 3 - 5 } Diets & FM protein replacement (\%) & Crude protein & Crude fat & Energy \\
\hline A & 0 (control) & $84.8 \pm 0.2^{\mathrm{c}}$ & $65.0 \pm 1.4^{\mathrm{b}}$ & $60.0 \pm 1.3^{\mathrm{c}}$ \\
B & 25 & $87.5 \pm 0.8^{\mathrm{b}}$ & $51.3 \pm 5.4^{\mathrm{c}}$ & $60.9 \pm 1.6^{\mathrm{c}}$ \\
C & 50 & $90.4 \pm 0.8^{\mathrm{a}}$ & $65.6 \pm 2.5^{\mathrm{b}}$ & $65.0 \pm 0.3^{\mathrm{b}}$ \\
D & 75 & $87.5 \pm 0.8^{\mathrm{b}}$ & $73.2 \pm 2.5^{\mathrm{a}}$ & $69.2 \pm 1.2^{\mathrm{a}}$ \\
E & 100 & $85.1 \pm 0.8^{\mathrm{c}}$ & $76.6 \pm 1.4^{\mathrm{a}}$ & $65.1 \pm 0.3^{\mathrm{c}}$ \\
\end{tabular}

Values with the same superscript are not significantly different $(\mathrm{P}<0.05)$.

The good growth rate, excellent condition and high survival in juvenile of mono sex Nile tilapia fed diets containing sesame seed meal protein up to $50 \%$ in the present study demonstrated that sesame seed meal protein had no adverse effect on fish performance at this level $(50 \%)$ of sesame seed meal protein. However, increasing levels of sesame seed meal protein up to 75 and $100 \%$ in the diets exhibited adverse effects.

In the present study, the proximate compositions of the experimental fish whole bodies at the start and the termination of the feeding trial are shown in Table (5). Moisture and ash contents were not significantly different $(\mathrm{P}>0.05)$ among all experimental diets and control diet. The highest value of protein contents was obtained on fish fed 50\% SSM protein (diet C) and the lowest was obtained in groups of fish fed 100\% sesame seed meal protein (diet E) and fish fed the control diet A. There were no significant differences $(\mathrm{P}>0.05)$ in protein content between fish fed $75 \%$ sesame seed meal diet D and control diet A. Incorporation of sesame seed meal in the diets increased significantly whole body fat content. The highest value of lipid content was recorded with fish fed $100 \%$ sesame seed meal protein (diet E) and the lowest was recorded with fish fed $25 \%$ sesame seed meal protein (diet B). The results of El-Saidy et al. (2005) and Deyab and Aml (2008) exhibited the same trend.

The results of apparent nutrients digestibility coefficients for mono sex Nile tilapia fingerlings fed on diets with partial and total replacement of fish meal by sesame seed meal are presented in Table (6). Sesame seed meal significantly influenced apparent digestibility of crude protein crude fat and energy. Crude protein digestibility was significantly highest for diet $\mathrm{C}$ that contained $50 \%$ sesame seed meal. The apparent digestibility coefficients of crude protein and energy for all sesame seed meal test diets were higher significantly compared with the control diet A (100\% FM). In case of fat digestibility, the highest values were recorded with fish fed diet E (100\% SSM) but, the lowest was recorded with fish fed diet B (25\% SSM). The values of apparent digestibility coefficients of fat for all sesame seed meal diets, except diet B were superior to the control diet A (100\% FM). Nibedita (2001) reported 
that fermented sesame seed meal had better protein and lipid digestibility in rohu, Labeo rohita (Hamilton) fingerlings.

In conclusion, the present study revealed that sesame seed meal protein can replace up to $50 \%$ of fish meal protein in commercial diets of mono sex Nile tilapia without any adverse effects on growth performance, feed utilization and whole body composition of fish. In addition, sesame seed meal used in the present study is available at much lower prices $(1.8 \mathrm{LE} / \mathrm{kg})$ than fishmeal $(7.50$ $\mathrm{LE} / \mathrm{kg}$ ) in many tropical and sub-tropical regions where tilapia culture is well established. However, further research should be conducted under the field conditions.

\section{ACKNOWLEDGMENTS}

The financial support provided by the Minufiya University College of Agriculture, Shebin El-Kom, Egypt, for our fish research laboratory is greatly acknowledged.

\section{REFERENCES}

AOAC (Association of Official Chemists). (1995) Official methods of analysis, $16^{\text {th }}$ edition, AOAC, Arlington, Virginia.

Beckstrom-Sternberg, S. M. and Duke, J. A. (1994). "The Phytochemical database".http//genome.cornell.edu/cgibin/WebAce/Webace?db=phytoc hemdb.

Carter, C. G. and Hauler, R. C. (2000). Fish meal replacement by plant meals in extruded feeds for Atlantic salmon, Salmo salar (L.). Aquacult., 185: 299-311.

De la Higuera, M.; Garcia-Gallego, M.; Sanz, A.; Cardenete, G.; Suarez, M. D. and Moyano, F. J. (1988). Evaluation of lupin seed meal as an alternative protein source in feeding of rainbow trout, Salmo gairdneri. Aquacult., 71: 37-50.

De Silva, S. S.; Keembiyahetty, C. N. and Gunasekera, R. M. (1988). Plant ingredient substitutes in Oreochromis niloticus (L.) diets: Ingredient digestibility and effect of dietary protein content on digestibility. J. Aqua. Trop., 3: 127-138.

Deyab, M. S. D. El-Saidy; Midhat A. El-Kasheif and Seham A. Ibrahim (2006). Evaluation of broken faba beans meal, Vicia faba (L.) as a partial or total replacement of fish meal in practical diets of Nile tilapia, Oreochromis niloticus (L.) fingerlings. J. Egyp. Aqua. Soc., 1: 34-46. 
Deyab, M. S. D. El-Saidy and Aml S. Saad (2008). Evaluation of cow pea seed meal, Vigna sinensis, as a dietary protein replacer for Nile tilapia (Oreochromis niloticus (L.) fingerlings. J. worl. Aqua. Soc, 39 (5): 636-645.

Diarra, S. S. and Usman, B. A. (2008). Performanceof laying hens fed graded levels of soaked sesame (Sesamum indicum) seed meal as a source of methionine. Inter. J. Poult. Sci., 7(4): 323-327.

Dipasa, (2003). Sesame honey bits. www.dipase.nl/seshobit.htm.

Duncan, D. B. (1955).Multiple range and multiple F tests: Biometrics, 11:1- 42.

El-Saidy, D.M.S.D. and Gaber, M. M. A. (1997). Total replacement of fish meal by soybean meal, with various percentages of supplemental Lmethionine, in diets for Nile tilapia Oreochromis niloticus fry. Ann. Agric. Sci., Moshtohor, 35 (3): 1223-1238.

El-Saidy, D.M.S.D. (1999). Evaluation of cottonseed meal as partial and complete replacement of fishmeal in practical diets of Nile tilapia (Oreochromis niloticus (L.) fingerlings. Egypt. J. Aquat. Biol. \& Fish., 3(4): 441- 457.

El-Saidy, D. M. S. and Gaber, M. M. A. (2001). Linseed: its successful use as a partial and complete replacement for fishmeal in practical diets for Nile tilapia (Oreochromis niloticus L.) pages 635-642 in A.M. Abdel-Samee, M.M. Shetaewi and S.I.Ghoneim, Second Inter. Conf. on Animal. Prod. \& Health in Semi-Arid Areas. Organized by Faculty of Environmental Agricultural Sciences, Suez Canal University, El-Arish, North Sinai, Egypt.

El-Saidy, D. M. S. and Gaber, M. M. A. (2002). Complete replacement of fishmeal by soybean with the dietary L-Lysine supplementation in Nile tilapia fingerlings. Journal of the World Aquacult. Soc., 33: 297-306.

El-Saidy D. M. S. D. and Gaber, M. M. A. (2004). Use of cottonseed meal supplemented with iron for detoxification of gossypol as a total replacement of fish meal in Nile tilapia, Oreochromis niloticus (L) diets. Aqua. Res. 35: 859-865.

El-Saidy, D. M. S. D.; Magdy, M. G. and Abd-Elshafy, A. SA.(2005). Evaluation of Cluster bean meal, Cyamposis tetragonoloba as a ditary 
protein source for common carp, Cyprinus carpio, L. J. World. Aqua. Soc., 36(3): 311-319.

El-Sayed, A. M.(1987). Protein and energy requirements of Tilapia zillii. Ph.D. diss., Michigan State University, East Lansing, MI, 147pp.

El-Sayed, A. M.(1990). Long-term evaluation of cotton seed meal as a protein source for Nile tilapia, Oreochromis niloticus (Linn.). Aqua, 84: 315320 .

Eric A. T. F.; Robert C. B. and Paul B. B.(2000). The effects of soybean-based diets, with and without amino acid supplementation, on growth and biochemical composition of juvenile American Lobster, Homarus americanus. Aqua, 189: 211-235.

Furukawa, H. and Tsukahara, H. (1966). On the acid digestion method for the determination of chromic oxide as an index substance in the study of digestibility of fish feed. Bull. Jpn. Soc. Sci. Fish., 32 (6): 502-508.

Gobi, B.(1981). Tropical feeds. Food and Agricultural Organization of the United Nations, Rome.

Hasan, M. R.; Macintosh, D.J. and Jauncey, K. (1997). Evaluation of some plant ingredients as dietary protein sources for common carp (Cyprinus carpio L.) fry. Aqua., 151: 55-70.

Hashim, R.; Saat, N. A. M. and Wong, C. H. (1994). Winged bean seed meal: its successful use as a partial replacement for fish meal in practical diets for red tilapia fry. In: The Third Asian Fisheries Forum. (ed by Chou, L. M., Munro, A. D., Lam, T. J., Chen, T. W., Cheong, L. K. K., Ding, J. K., Hooi, K. K., Khoo, H. W., Phang, V. P. E., Shim, K. F. and Tan, C. H.), pp.660-662. Asian Fisheries Society, Manila, Philippines.

Hossain, M. A. and Jauncey, K. (1989). Nutritional evaluation of some Bangladeshi oilseeds meals as partial substitutes for fish meal in the diet of common carp, Cyprinus carpio L. Aqua. Fish. Manag, 20: 225-260.

Jackson, A.J.; Capper, B.S. and Matty, A. J. (1982). Evaluation of some plant proteins in complete diets for tilapia Sarotherodon mossambicus. Aqua., 27:97-109.

Jobling, M. (1983). A short review and critique of methodology used in fish growth and nutrition studies. J. Fish Biol., 23: 685. 
Kaneko, K.; Yamasaki, K.; Tagawa,Y.; Tokunaga, M.; Tobisa, M. and Furuse, M. (2002). Effects of dietary sesame meal on growth, meat ingredient and lipid accumulation in broilers. Jpn. Poult. Sci. 39: 56-62.

Lee, S.C.; Jeong, S. M.; Kim, S.Y.; Nam, K. C. and Ahn. D. U. (2005). Effect of far-infrared irradiation on the antioxidant activity of defatted sesame meal extracts. J. Agric. Food Chem., 53:1495-1498.

Lim C. and Dominy, W. (1991). Utilization of plant proteins by warm water fish. In: Proceedings of the Aquaculture Feed Processing and Nutrition Workshop [Akiyama D.M., R.K.H. Tan (eds.)]. American Soybean Association, Singapore: pp.163-172

Lovell, R. T. (1989). Nutrition and Feeding of Fish. Van Nostrand Reinhold, New Yourk, NY.

Mamputu, M. and Buhr, R. J. (1991). Effects of substituting sesame meal for soyabean meal on layer performance. Poult. Sci., 70: 77pp.

Mamputu, M. and Buhr, R. J. (1995). Effects of substituting sesame meal for soyabean meal on layer and broiler performance. Poult. Sci., 74: 672687

Maynard, L. A. and Loosli, J. K. (1969). Animal Nutrition, 6th edition. McGraw Hill New York, USA.

Mukhopadhyay, N. and Ray, A. K. (1999). Improvement of quality of sesame Seasamum indicum seed meal protein with supplemental amino acids in feeds for rohu Labeo rohita (Hamilton) fingerlings. Aquaculture Research, 30 (8): 549-557.

Nahm,K.H. (2007). Efficient phosphorus utilization in poultry feeding to lessen the environmental impact of excreta. World's Poult. Sci., 63: 625-654.

Nibedita, M. (2001). Effect of fermentation on apparent total and nutrient digestibility of sesame (Seasamum indicum) seed meal in rohu, Labeo rohita (Hamilton) fingerlings. Abbrev. : Acta Ichthyol. Piscat. 31 (2): 19-28

NRC (National Research Council) (1993). Nutrient requirements of warm water fishes and shellfishes, National Academy of Sciences, Washington, DC, USA. 
Ram, R., D. Catlin, J. Romero, and C. Cowley (1990). Sesame meal for soyabean meal on layer performance. Poult. Sci., 70: 77.

Richardson, N. I.; Higgs, D. A.; Beames, R. M. and MC Bride, J. R. (1985) Influence of dietary calcium, phosphorus, Zinc and sodium phytate levels on cataract incidence, growth and histopathology in juvenile Chinook salmon, Oncorhynchus tshayvytscha. J. Nut. 115: 553-567.

Santiago, C.B. and Lovell, R.T. (1988). Amino acid requirements for growth of Nile tilapia. J. Nut., 188:1540-1546.

SAS (Statistical Analysis System) (1988). SAS / STAT user's guide release 6.03 edition. SAS Institute Inc. Cary, North Carolina, USA.

Tacon, A.G.J. (1993). Feed ingredient for warmwater fish: Fishmeal and other processed feed stuffs. FAO Fisheries Circular No. 856. FAO, Rome.

Wee, K.L. (1991). Use of non-conventional feedstuffs of plant origin as fish feeds- is it practical and economically feasible? In: Fish Nutrition Research in Asia. Proceedings of the Fourth Asian Fish Nutrition Workshop [De Silva S.S. (ed.)]. Asian Fisheries Society, Manila, Philippines: pp.13-32.

Zar, J. H. (1984). Bio-statistical Analysis, 2nd edition. Prentice-Hall International, Inc. Englewood Cliffs, New Jersey, USA. 